\title{
First record of Acanthuridae (surgeonfish) from the Miocene deposits of the Medvednica Mt.
}

\author{
Kristina Tripalo ${ }^{1}$, Sanja Japundžić ${ }^{2}$, Jasenka Sremac ${ }^{3}$ and Marija Bošnjak ${ }^{2}$ \\ 1 Šestinski vrh 43a, Zagreb, Croatia; (ktripalo@gmail.com) \\ ${ }^{2}$ Croatian Natural History Museum, Department of Geology and Paleontology, Demetrova 1, Zagreb, Croatia; (sanja.japundzic@hpm.hr, marija.bosnjak@hpm.hr) \\ ${ }^{3}$ University of Zagreb, Faculty of Science, Department of Geology, Division of Geology and Paleontology, Horvatovac 102a, Zagreb, Croatia; \\ (corresponding author: jsremac@geol.pmf.hr) \\ doi: $10.4154 / g c .2016 .15$

\section{Article history:}

Manuscript received September 02, 2015 Revised manuscript accepted March 03, 2016 Available online May 16, 2016

Keywords: Central Paratethys, Medvednica Mt. Miocene, Badenian, Acanthuridae

\begin{abstract}
Middle Miocene deposits at the Dubravica locality in SW Medvednica Mt. (N Croatia) contain various marine fossils, including one tooth of the surgeonfish (Acanthuridae). This is the first such record in Croatia and the second in the wider region, besides the Vienna Basin. The appearance of surgeonfishes in the Paratethys coincides with the Miocene thermal maximum. Their distribution was probably controlled by available reef habitat and their palaeobiogeography and migration routes are yet to be studied.
\end{abstract}

\section{INTRODUCTION}

Northern and north-eastern Croatia during the Miocene epoch were covered by the Paratethys Sea (Fig. 1). Abundant and diverse marine fossils can be found in sedimentary rocks of this age. Medvednica Mt. acted as an island near the SW coast of the Paratethys, and Miocene shelf deposits are exposed today in the form of a belt around the mountain core.

Middle Miocene marine environments of Medvednica Mt. were divided into the "Dolje" development in the south-western part of Medvednica Mt., the "Čučerje" development in the central part of Medvednica Mt., and the "Zelina" development in the south-eastern part of Medvednica Mt., each characterized by different fossil assemblages (KOCHANSKY, 1944).

Miocene deposits of the south-western part of Medvednica Mt., considered to be a part of the "Dolje" development, have been studied by many authors (e.g. KOCHANSKY, 1944; KOCHANSKY-DEVIDÉ, 1957; ŠIKIĆ et al., 1977, 1979; KOCHANSKY-DEVIDÉ \& BAJRAKTAREVIĆ, 1981; VRSALJKO et al., 2006, 2007; BOŠNJAK et al., 2014).

The Dubravica locality (Fig. 1), records the first occurrence of fossil Acanthuridae in Croatia, and is situated on the south- western slopes of Medvednica Mt. The surgeonfish tooth was discovered during recent field work (BOŠNJAK et al., 2014; TRIPALO et al., 2015).

\section{GEOLOGICAL SETTING}

The investigated area is a part of the Miocene deposits belt surrounding Medvednica Mt., and is situated on its south-western slopes (Fig. 1). Geological and palaeontological features of this area were summarized in publications following the Basic Geological Mapping, by ŠIKIĆ et al. (1977, 1979), and later by ŠIKIĆ (Edit.) (1995).

During the Miocene, the whole area palaeogeographically belonged to the south-western margins of the Central Paratethys (Fig. 1), and geotectonically to the Pannonian Basin System (PAVELIĆ, 2002).

An approximately 16 metre high subvertical outcrop, with sedimentary rocks of ca. $11.5 \mathrm{~m}$ in thickness, is exposed at the Dubravica locality near the path leading to the Veternica Cave (Fig. 2). Triassic dolomites in the base are transgressively overlain with dolomitic breccias, which gradually pass into brecciasconglomerates, and are later replaced with floatstones containing
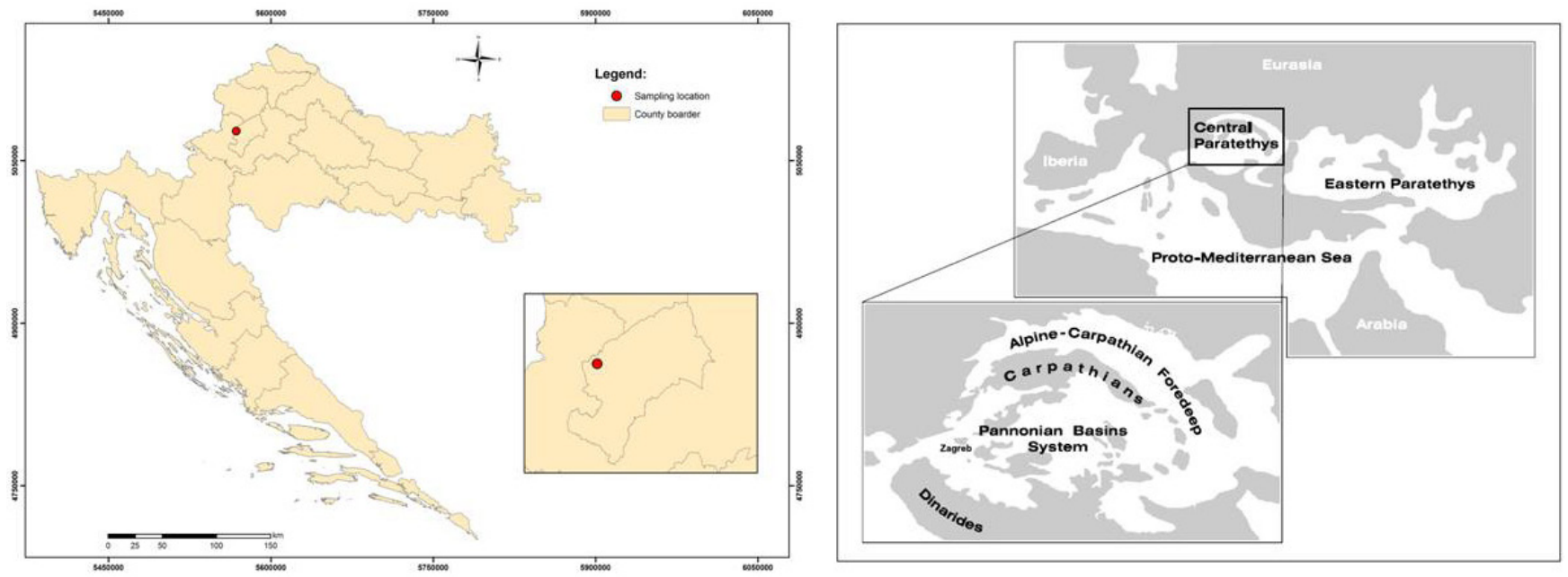

Figure 1. Location of the Dubravica locality and palaeogeographic map of Central Paratethys (after VRSALJKO et al., 2006; from BOŠNJAK et al., 2014). 


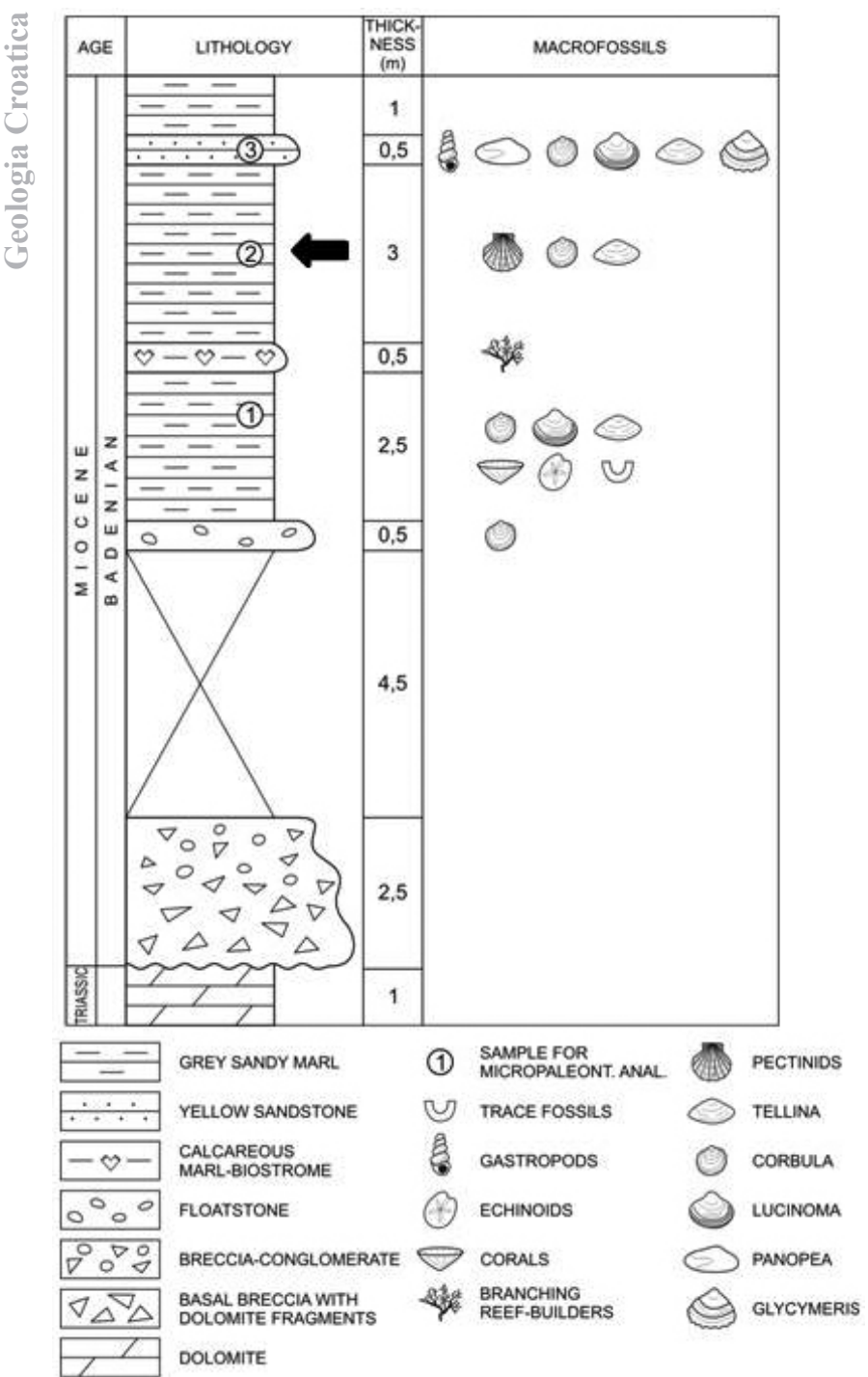

Figure 2. Schematic geological column of the Dubravica locality (after BOŠNJAK et al., 2014). Numbers 1, 2, and 3 mark investigated layers; 1 : dark grey marl, 2 : light grey marl, 3: intercalation of yellow sandstone. Location of the horizon with the surgeonfish tooth is marked with arrow.

bivalve moulds and dispersed dolomitic cobbles. A horizon composed of dark grey marl, ca. $2.5 \mathrm{~m}$ thick, overlies this layer. It contains molluscs, solitary corals, bryozoans, echinoids and trace fossils. The upper part of the column is characterized by a lightgrey marl, ca. 3 m thick, with molluscs. An intercalation of yellowish sandstone with bivalves and gastropods, ca. $0.5 \mathrm{~m}$ thick, occurs within this horizon (Fig. 2).

In the vicinity of the sampled section, ca. $15 \mathrm{~m}$ towards the south, marls are laterally replaced with a coralgal reef buildup („Lithothamnium limestone“, sensu KOCHANSKY, 1944) of contemporary age. The visible part of this buildup is ca. $10 \mathrm{~m}$ wide and ca. $5 \mathrm{~m}$ high.

Marls and sandstones from the Dubravica locality contain a rich microfossil assemblage present in all of the three analyzed layers (Fig. 2), containing juvenile and fragmented molluscs, foraminifera, ostracods, bryozoans, fish teeth and bones, echinoid spines and sponge spicules. In the light grey marl layer (Fig. 2), a fish tooth from the Acanthuridae family was discovered (BOSNJAK et al., 2014; TRIPALO et al., 2015). The collected fossil assemblages when compared with the available published data (e.g. KOCHANSKY, 1944; ŠIKIĆ et al., 1977, 1979; ŠIKIĆ, 1995;
PIKIJA in VELIĆ \& VLAHOVIĆ, 2009; BAJRAKTAREVIĆ \& KOCHANSKY-DEVIDÉ, 1981; VRSALJKO et al., 2006, 2007), suggest that the deposits are of Middle Miocene (Upper Badenian) age (BOŠNJAK et al., 2014; BOŠNJAK et al., 2015).

\section{MATERIAL AND METHODS}

Selected samples from the three layers of the Dubravica locality (Fig. 2) were analyzed following wet sieving. Samples were prepared in the Wet laboratory, at the Faculty of Science in Zagreb, Department of Geology, Division of Geology and Palaeontology. Soft marls were crushed, then soaked in the water with hydrogen peroxide. After twenty-four hours, samples were flushed through the $0.5,0.2$ and $0.125 \mathrm{~mm}$ sieves. Special attention was given to those with mesh size of 0.2 and $0.125 \mathrm{~mm}$ as these were the fractions where fossil fish teeth were discovered. The surgeonfish tooth was found on the $0.2 \mathrm{~mm}$ sieve.

\section{RESULTS}

Fish remains are common fossils in the Neogene deposits of Central Paratethys. Fish teeth are particularly common and well preserved reflecting their solid construction. From the Badenian deposits of Medvednica Mt., fossil teeth of Chrysophrys sp., Odontaspis sp., Lamna sp., and Mylobatis sp. have been observed to date (KOCHANSKY, 1944; ŠIKIĆ et al., 1979). Among other microfossils from the investigated Dubravica locality, one tooth from the Acanthuridae was also found.

\section{CLASS: Actinopterygii (KLEIN, 1885) \\ ORDER: Perciformes (BLEEKER, 1859) \\ FAMILY: Acanthuridae BONAPARTE, 1832}

The Acanthuridae includes fishes whose common name (surgeonfishes) derives from the presence of a scalpel-like modified scale on the caudal peduncle (WINTERBOTTOM, 1993), which may be used in inter- and intra-specific aggressive behaviour (RANDALL, 2001).

Today, acanthurids all live in tropical and subtropical seas, and are one of the dominant groups of fish on the coral reefs (PURCELL \& BELLWOOD, 1993 and references therein; SORENSON et al., 2013; LUDT et al., 2015). Their modern geographic distribution is similar to other reef fish families and largely reflects Neogene biogeographic influences (PELLISSIER et al., 2014).

Surgeonfishes are primarily herbivores, but consume a relatively wide variety of dietary resources, including planktonic animal matter, organic detritus and invertebrates (SORENSON et al., 2013). Dentition can vary dramatically within and across genera, and it is strongly related to diet (TYLER, 1970) (Fig. 3).

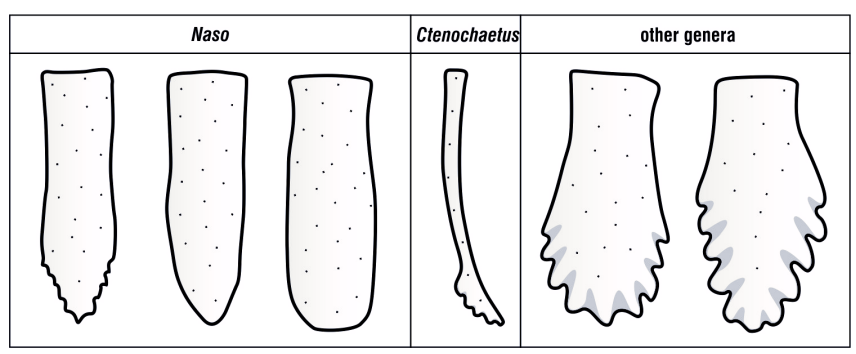

Figure 3. Examples of teeth of the Acanthuridae family: Naso - fixed teeth, mostly conical but slightly distally compressed, with denticulations variously small, minute or absent; Ctenochaetus - numerous, elongated, moveable teeth well denticulated on one side only; other genera (Paracanthurus, Zebrasoma and Acanthurus) - fixed teeth, compressed with well developed denticulations (after TYLER, 1970). 


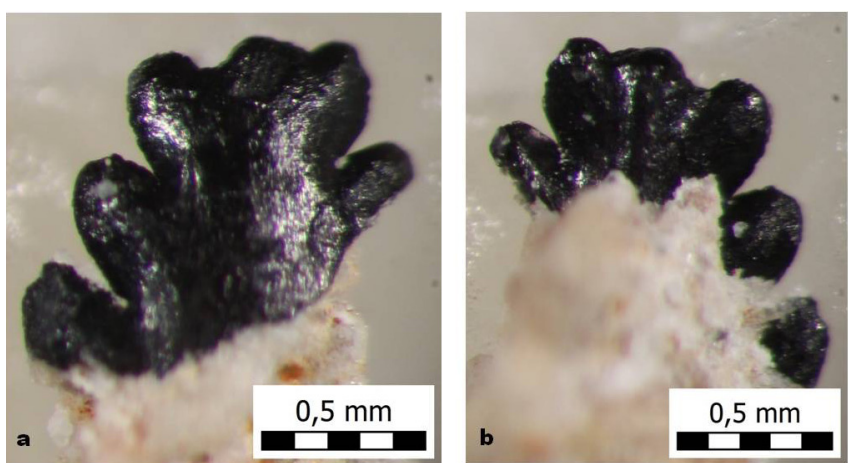

Figure 4. Acanthuridae fossil tooth, a) labial side; b) lingual side.

Acanthuridae gen. et sp. indet.

Material: one partially preserved tooth with accreted sediment (Fig. 4)

As shown on Fig. 4, the exposed part of the small incisiform tooth is almost black in color. Dimension of the tooth (in $\mathrm{mm}$ ) are: 1.95 height, 1.13 width.

The tooth has a multidenticulate structure typical of the majority of acanthurids. One apical denticulation, two denticulations on the right and three on the left side of the tooth are visible. Denticulations on both sides increase in size towards the base of the teeth. The investigated tooth is slightly curved inward. Its surface is almost smooth on both the labial and lingual side (Fig. 4). Considering the partial tooth preservation, and range of genera with this configuration, determination at the generic level was not possible.

\section{DISCUSSION}

Fossil Acanthuridae or surgeonfishes are among the best studied fossil percomorph fishes.

The rich fossil record indicates that acanthurids reached a significant diversity by the Middle Eocene (SORENSON et al., 2013). Abundant and diverse surgeonfishes from the Monte Bolca locality, at least 14 extinct genera and 16 species, were studied by several authors (BLOT \& TYLER, 1990; SORBINI \& TYLER, 1998a, b; TYLER, 1999, 2005a, b; TYLER \& BANNIKOV, 2000). The Monte Bolca fish assemblage represents the oldest known fauna that may be defined as a coral reef fish assemblage (BELLWOOD, 1996) and is a key fossil deposit at the birth of modern coral reefs (BELLWOOD et al., 2014). Several genera share the multidenticulate tooth form at this time (BELLWOOD et al., 2014) suggesting that they may have been feeding on short algal turf (PURCELL \& BELLWOOD, 1993).

Some fossil taxa of the Acanthuridae are known from the Oligocene deposits (TYLER, 2000; TYLER \& SORBINI, 1998; TYLER \& MICKLICH, 2011).

Previously Miocene surgeonfishes have only been reported from Sulawesi (TYLER, 1997) and from the Miocene of the Vienna Basin (MEYER, 1842; SCHULTZ, 2003). Austrian acanthurid fish teeth were described as Acanthurus haueri (MEYER, 1842). They are of similar size as the specimen from Dubravica, but differ from it in shape. As we are lacking other parts of the skeleton, we can only speculate whether this is a different species, but it is also possible that the tooth belongs to the same species, but had a different position within the jaws (SCHULTZ \& BELLWOOD, 2004).

Miocene reefs and reef-like structures in Paratethys which were suitable habitats for acanthurids were predominantly com- posed of coralline algae: Lithothamnion valens, Phymatoliton calcareum and Mesophyllum roveretoi (BASSO et al., 2008), sometimes in association with bryozoans and, sporadically, corals (VRSALJKO et al., 2006). Interestingly only one other herbivorous reef fish has been recorded from this region, the parrotfish Calotomus from the Badenian of Austria (BELLWOOD \& SCHULTZ, 1991).

Findings of acanthurid teeth in the Paratethys realm coincide with the Miocene thermal maximum. We can discuss why are these finds so scarce; the small size of acanthurid teeth and their rather bizarre shape may be the reason that palaeontologists do not register or recognize them in the sieved material.

The Croatian surgeonfish record opens discussion of the possible ancestral populations and fish migration routes, but such study requires reexamination of other contemporary rocks along the Paratethys reef formations and the possible discovery of more surgeonfish remains.

\section{CONCLUSIONS}

A small fish tooth from the Dubravica locality in the south-western part of Medvednica Mt. represents the first record of surgeonfishes (Acanthuridae) in Croatia. In the nearby area, similar teeth from Miocene deposits of the Vienna Basin have been referred to the type Acanthurus haueri (MEYER, 1842; SCHULTZ, 2003).

The tooth from the Dubravica locality differs from the Austrian samples in shape, but is of similar size. It may belong to another species, or to the same species, but from a different position within the jaw.

The appearance of acanthurids in the Paratethys corresponds with the Miocene thermal maximum, and it opens discussion about the ancestral populations and possible biogeographic extent of the Acanthuridae across Paratethys.

Palaeoecologically it was controlled by distribution of suitable benthic habitats, in this case coralgal or coralgal-bryozoan reef buildups.

\section{ACKNOWLEDGMENT}

The authors thank Prof. David BELLWOOD from the College of Marine and Environmental Sciences, James Cook University, Townsville, Australia, for help in fish tooth analyzing techniques and discussion support. We wish to thank the Division of Geology and Palaeontology, Department of Geology, Faculty of Science, University of Zagreb, and the Croatian Natural History Museum, for their support. We are grateful to both reviewers for their useful comments and suggestions.

\section{REFERENCES}

BASSO, D., VRSALJKO, D. \& GRGASOVIĆ, T. (2008): The coralline flora of a Miocene maërl: the Croatian "Litavac".- Geologia Croatica, 61/2-3, 333-340. doi: 10.4154/GC.2008.25

BELLWOOD, D.R. (1996): The Eocene Fishes of Monte Bolca; the earliest coral reef fish assemblage.- Coral Reefs, 15/1, 11-19. doi: 10.1007/BF01626074

BELLWOOD, D.R., GOATLEY, C.H.R., BRANDL, S.J. \& BELLWOOD, O. (2014): Fifty million years of herbivory on coral reefs: fossils, fish and functional innovations.- Proc.of the Royal Society B, 281/1781, 1-8. doi: 10.1098/rspb.2013.3046

BELLWOOD, D.R. \& SCHULTZ, O. (1991): A Review of the Fossil Record of the Parrotfishes (Labroidei: Scaridae) with a Description of a New Calotomus Species from the Middle Miocene (Badenian) of Austria.- Ann. Naturh. Museum Wien, $92 \mathrm{~A}, 55-71$.

BLOT, J. \& TYLER, J.C. (1990): New genera and species of fossil surgeonfishes and their relatives (Acanthuroidei, Teleostei) from the Eocene of Monte Bolca, Italy, with application of the Blot formula to both fossil and recent forms.- St. Ric. Giac. Terz. Bolca, 6, 13-92. 
BOŠNJAK, M., KARAICA, B., SREMAC, J., VRSALJKO, D., HAJEK-TADESSE, V., GRUBER, A., JEFTINIĆ, S.\& POSEDI, N. (2014): Middle Miocene fossil assemblages and environments in the wider area of Veternica cave (SW Medvednica Mt., NW Croatia)-- Acta Mineralogica-Petographica, Abstract series (5th International Students Geological Congress), Volume 8, p. 11.

BOŠNJAK MAKOVEC M., KARAICA, B., SREMAC, J., VRSALJKO, D., HAJEKTADESSE, V., GRUBER, A., JEFTINIĆ, S. \& POSEDI, N. (2015): Miocene Dolje development-Dubravica locality.-In: VRSALJKO, D., SREMAC, J. \& BOŠNJAK MAKOVEC, M. (eds.): International Scientific Meeting $100^{\text {th }}$ Birth Anniversary of Vanda Kochansky-Devidé, Full Member of Academy, Zagreb, $9^{\text {th }}-11^{\text {th }}$ April, Field trip Excursion Guidebook, 3-7.

KOCHANSKY, V. (1944): Fauna marinskog miocena južnog pobočja Medvednice (Zagrebačke gore). [Miozäne marine Fauna des südlichen Abhanges der Medvednica (Zagreber Gebirge)].- Geol. vjesnik Hrv. drž. geol. zav. Hrv. drž. geol. muz., Vol. 2/3,171-280

KOCHANSKY-DEVIDÉ, V. (1957): O fauni miocena i o tortonskom ,šliru“ Medvednice (Zagrebačka gora). [Über die Fauna des marinen Miozäns und über den tortonischen „Schlier“ von Medvednica (Zagreber Gebirge)].- Geol. vjesnik, 10 (1956), 39-50.

KOCHANSKY-DEVIDÉ, V. \& BAJRAKTAREVIĆ, Z. (1981): Miocen (baden i sarmat) najzapadnijeg ruba Medvednice. [Miozän (Baden und Sarmat) des westlichen Randes von Medvednica Gebirge (Kroatien, Jugoslawien)].- Geol. vjesnik, 33, 43-48.

LUDT, W. B., ROCHA, L. A., ERDMANN, M. V. \& CHAKRABARTY, P. (2015): Skipping across the tropics: The evolutionary history of sawtail surgeonfishes (Acanthuridae: Prionurus). Molecular Phylogenetics and Evolution, 84, 166-172. doi: 10.1016/j.ympev.2014.12.017

MEYER, H. v. (1842): Iguana (?) Haueri, aus dem Tertiärgebilde des Wiener Beckens. ${ }^{-}$ Beiträge zur Petrefacten-Kunde, 5, 33-34.

PAVELIĆ, D. (2002): The South-Western Boundary of Central Paratethys.- Geologia Croatica, 55/1, 83-92. doi: 10.4154/GC.2002.08

PELLISSIER, L, LEPRIEUR, F., PARRAVICINI, V., COWMAN, P. KULBICKI, M., LITSIOS, G., OLESEN, S., WISZ, M. S., BELLWOOD, D.R., \& MOUILLOT, D. (2014): Quaternary coral reef refugia preserved fish diversity.- Science, 344, 1016-1019. doi: 10.1126/science. 1249853

PIKIJA, M. (2009): Litavac i klastične naslage s vulkanitima (baden - $\mathrm{M}_{4}$ ).- In: VELIĆ, I. \& VLAHOVIĆ, I. (eds.): Tumač Geološke karte Republike Hrvatske 1:300.000 (Geological Map of the Republic of Croatia). Hrvatski geološki institut, Zagreb, 86-87.

PURCELL, S. W. \& BELLWOOD, D. R. (1993): A functional analysis of food procurement in two surgeofishes species Acanthurus nigrofuscus and Ctenochaetus striatus (Acanthuridae).- Envir. Biology of Fishes, 37, 139-159.

RANDALL, J. E. (2001): Surgeonfishes of Hawai'i and the World.- Mutual Publish. and Bishop Museum Press Hawai'i.

SCHULTZ, O. (2003): The Middle Miocene Fish Fauna (excl. otolithes) from Mülbach am Manhartsberg and Grund near Hollabrunn, Lower Austria.- Ann. Naturh. Museum Wien, 104 A, 185-193.

SCHULTZ, O. \& BELLWOOD, D. R. (2004): Trigonodon oweni and Asima jugleri are different parts of the same species Trigonodon jugleri, a Chiseltooth Wrasse from the Lower and Middle Miocene of Central Europe (Osteichthyes, Labridae, Trigonodontinae).- Ann. Naturh. Museum Wien 105A, 287-305.

SORBINI, L. \& TYLER, J.C. (1998a): A new genus and species of Eocene surgeonfish (Acanthuridae) from Monte Bolca, Italy, with similarities to the Recent Zebrasoma.- St. Ric. Giac. Terz. Bolca, 7, 7-19.

SORBINI, L. \& TYLER, J.C. (1998b): A new species of the Eocene surgeon fishgenus Pesciarichthys from Monte Bolca, Italy, with comments on caudal peduncle armature and supraneurals in acanthurids.- St. Ric. Giac. Terz. Bolca, 7, 21-34.

SORENSON, L., SANTINI, F., CARNEVALE, G. \& ALFARO, M. E. (2013): A multilocus timetree of surgeonfishes (Acanthuridae, Percomorpha) with revised family taxonomy.- Mol. Phylogenet. Evol., 68/1, 150-160. doi: 10.1016/j.ympev.2013. 03.014

ŠIKIĆ, K., BASCH, O. \& ŠIMUNIĆ, A. (1977): Osnovna geološka karta SFRJ 1:100000, list Zagreb L38-80 [Basic Geological Map of SFRY 1:100000, Zagreb sheet - in Croatian].- Institut za geološka istraživanja, Zagreb, Savezni geološki zavod, Beograd.

ŠIKIĆ, K., BASCH, O. \& ŠIMUNIĆ, A. (1979): Osnovna geološka karta SFRJ 1:100000. Tumač za list Zagreb L 38-80 [Basic Geological Map of SFRY 1:100000, Geology of the Zagreb sheet - in Croatian].- Institut za geološka istraživanja, Zagreb (1972) Savezni geološki zavod, Beograd, $81 \mathrm{p}$.

ŠIKIĆ, K. (1995): Geološki vodič Medvednice. Institut za geološka istraživanja INAIndustrija nafte, d.d., Zagreb, 199 p.

TRIPALO, K., JAPUNDŽIĆ, S., SREMAC, J. \& BOŠNJAK MAKOVEC, M. (2015): Prvi nalaz ribe-kirurg u miocenskim naslagama Medvednice. [First record of the surgeonfish from the Miocene deposits of Mt. Medvednica].- In: MAUCH LENARDIĆ, J., HERNITZ KUČENJAK, M., PREMEC FUĆEK, V. \& SREMAC, J. (eds.): International Scientific Meeting $100^{\text {th }}$ Birth Anniversary of Vanda Kochansky-Devidé, Full Member of Academy - Zagreb, $9^{\text {th }}-11^{\text {th }}$ April 2015, Abstracts, Hrvatska akademija znanosti i umjetnosti, Zagreb, 80-81.

TYLER, J.C. (1970): Osteological aspects of interrelationships of surgeon fish genera (Acanthuridae).- Proc. Acad. Nat. Sci. Phila., 122, 87-124.

TYLER, J.C. (1997): The Miocene fish Marosichthys, aputative tetraodontiform, actually a perciform surgeon fish (Acanthuridae) related to the recent Naso - - Beaufortia, $47,1-10$.

TYLER, J.C. (1999): A new genus and species of surgeon fish (Acanthuridae) with a unique dorsal-fin pterygiophore arrangement from the Eocene of Monte Bolca, Italy.- St. Ric. Giac. Terz. Bolca, 7, 245-256.

TYLER, J.C. (2000): Arambourgthurus, a new genus of hypurostegic surgeon fish (Acanthuridae) from the Oligocene of Iran, with a phylogeny of the Nasinae.- Geodiversitas, 22, 525-537.

TYLER, J.C. (2005a): Redescription and basal phylogenetic placement of the acanthurid surgeon fish Gazolaichthys vestenanovae from the Eocene of Monte Bolca, Italy (Perciformes; Acanthuroidea).- St. Ric. Giac. Terz. Bolca, 11, 97-117.

TYLER, J.C. (2005b): A new genus for the surgeon fish Acanthurus gaudryi De Zigno 1887 from the Eocene of Monte Bolca, Italy, a morphologically primitive basal taxon of Acanthuridae (Acanthuroidea, Perciformes).- St. Ric. Giac. Terz. Bolca, $11,149-163$.

TYLER, J.C. \& BANNIKOV, A.F. (2000): A new species of the surgeon fishgenus Tauichthys from the Eocene of Monte Bolca, Italy (Perciformes, Acanthuridae).Boll. Mus. Civ. St. Nat. Verona, 24, 29-36.

TYLER, J.C. \& SORBINI, L. (1998): On the relationships of Eonaso, an Antillean fossil surgeon fish (Acanthuridae).- St. Ric. Giac. Terz. Bolca, 7, 35-42.

TYLER, J.C. \& MICKLICH, N.R. (2011): A new genus and species of surgeon fish (Perciformes, Acanthuridae) from the Oligocene of Kanton Glarus. Switzerland.Swiss J. Palaeontol., 130, 203-216. doi: 10.1007/s13358-011-0016-5

VRSALJKO, D., PAVELIĆ, D., MIKNIĆ, M., BRKIĆ, M., KOVAČIĆ, M., HEĆIMOVIĆ, I., HAJEK-TADESSE,V., AVANIĆ, R. \& KURTANJEK, N. (2006): Middle Miocene (Upper Badenian/Sarmatian) Palaeoecology and Evolution of the Environments in the area of Medvednica Mt. (North Croatia).- Geologia Croatica, 59/1, 51-63. doi: $10.4154 /$ GC.2006.04

VRSALJKO, D., HEĆIMOVIĆ, I. \& AVANIĆ, R. (2007): Miocene deposits of Northern Croatia.- In: GRGASOVIĆ, T. \& VLAHOVIĆ, I. (eds.): 9th International Symposium on Fossil Algae - Croatia 2007, Field Trip Guidebook and Abstracts. Croatian Geological Survey, Zagreb, 143-153.

WINTERBOTTOM, R. (1993): Myological evidence for the phylogeny of recent genera of surgeonfishes (Percomorpha, Acanthuridae), with comments on the Acanthuroidei.- Copeia, 1, 21-39. doi: 10.2307/1446292 